\title{
UPAYA PENCEGAHAN TINDAK PIDANA TERORISME BERBASIS PERAN SERTA MASYARAKAT OLEH SATUAN BRIMOB KEPOLISIAN DAERAH SUMBAR
}

\author{
M. Aulia Zikra Cheni \\ Program Magister Ilmu Hukum, Universitas Ekasakti, Padang, Indonesia \\ Email: mazikrac@gmail.com
}

\begin{abstract}
Efforts to Prevent Terrorism Crimes Based on Community Participation by the West Sumatra Police Mobile Brigade Unit are through a community approach. The activities carried out are by making folk art events such as randai, involving religious leaders with lectures in mosques. Carry out patrols and social dialogue with youth at the RT and school or campus levels. The social message contains information and appeals not to follow radicals and to be careful of all forms of activities that lead to criminal acts. Another form of participation is that Satbrimob members embrace community leaders and traditional leaders so that every parent involved is involved in providing warnings, education, and knowledge to children. This effort can be effective in dealing with problems because early detection can be done by families. Lack of synergy between the Satbrimob and Ditintelkam, in relation to community development and in empowering the community in efforts to eradicate theorists. impression that the government is very important that prevention prevention is a central concern. Prevention activities that are often carried out by the West Sumatra Police Satbrimob use language that is considered too high and does not pay attention to local culture. Satbrimob also lacks direct dialogue in the community to convey the narrative of preventing terrorism. This has implications for the messages conveyed that do not reach the community level.
\end{abstract}

Keywords: Prevention, Terrorism, Community Participation

\begin{abstract}
ABSTRAK
Upaya Pencegahan Tindak Pidana Terorisme Berbasis Peran Serta Masyarakat Oleh Satuan Brimob Kepolisian Daerah Sumbar adalah melalui pendekatan kemasyarakatan. Kegiatan yang dilakukan adalah dengan membuat acara kesenian rakyat seperti randai, melibatkan tokoh agama dengan kegiatan ceramah pada mesjid. Melaksanakan patroli dan dialog sosial dengan pemuda di tingkat Rt dan sekolah atau kampus. Pesan sosial tersebut berisikan informasi dan himbauan agar tidak mengikuti paham radikal dan berhati hati terhadap segala bentuk kegiatan yang mengarah kepada perbuatan terorisme. Bentuk partisipasi yang lain adalah anggota Satbrimob merangkul tokoh masyarakat dan tokoh adat agar meminta setiap orang tua yang ada ikut terlibat dalam memberikan peringatan, pendidikan, maupun pengetahuan terhadap anak-anak. Upaya ini dapat efektif untuk menghadapi persoalan terorisme pasalnya deteksi dini dapat dilakukan keluarga. Kurangnya Sinergitas Antara Pihak Satbrimob dengan Ditintelkam, dalam Kaitannya Pembinaan ke masyarakat dan dalam memberdayakan masyarakat dalam upaya pemberantasan teorisme. kesan bahwa pemerintah sangat menekankan bahwa urusan pencegahan terorisme adalah urusan pusat. Kegiatan pencegahan
\end{abstract}


yang kerap dilakukan oleh Satbrimob Polda Sumbar menggunakan bahasa yang dianggap terlalu tinggi dan kurang mengindahkan budaya lokal. Satbrimob juga minim dialog langsung di tengah masyarakat untuk menyampaikan narasi pencegahan terorisme. Hal ini berimplikasi pada acapnya pesan yang disampaikan tidak mengena di tingkat masyarakat.

Kata Kunci : Pencegahan, Terorisme, Peran Serta Masyarakat

\section{PENDAHULUAN}

Terorisme ialah salah satu wujud kesalahan yang jadi pancaran di bumi, sebab aksi itu memakai kekerasan ataupun mengecam dengan kekerasan kepada warga ataupun keamanan nasional apapun motifnya, alhasil menghasilkan perasaan rawan serta kekhawatiran. ${ }^{1}$ Semenjak berdirinya Negeri Kesatuan Republik Indonesia (NKRI), Indonesia tidak sempat bebas dari bahaya teror serta banyak pihak memperhitungkan Indonesia hadapi bahaya terorisme semenjak dini tahun 2000-an dan jadi pusat atensi bumi sebab selaku incumbent serta follower dalam aspek terorisme. ${ }^{2}$ Pada dasarnya, terorisme ditatap selaku kesalahan luar lazim (Extraordinary Crime) serta ialah sesuatu wujud perang garis besar, sejenis perang dingin dengan kedudukan pengganti yang berlainan. Wujud teror sendiri bisa dicoba dengan bermacam metode aksi, antara lain ancaman serta bahaya, penganiayaan, penyanderaan, peledakan, pemboman, pemalsuan, serta pembakaran. Pada era saat ini, kejadian terorisme di Indonesia bukan ialah perihal yang asing lagi.

Memandang banyaknya kesalahan terorisme, hingga butuh dicoba counter terrorism ataupun perang garis besar melawan terorisme. Dalam perihal penyelesaian terorisme oleh penguasa salah satunya merupakan dengan pemberlakukan Hukum No 5 Tahun 2018 mengenai Pergantian Atas Hukum No 15 Tahun 2003 Mengenai Penentuan Peraturan Penguasa Pengganti Hukum No 1 Tahun 2002 Mengenai Pemberantasan Perbuatan Kejahatan Terorisme Jadi Hukum.

Ada sebagian pendekatan, Angkatan darat (AD)' ha Aljunied menarangkan terdapat 2 pendekatan penting dalam perang garis besar melawan terorisme. ${ }^{3}$ Awal, pendekatan keras (Hard Approach), membutuhkan keikutsertaan raga yang mematahkan konsep merusak teroris, semacam pengeboman. Lewat legislatif, yudikatif serta administrator yang membuktikan perang negeri melawan terorisme, negeri modern memakai tata cara semacam penahanan, pengawasan, intelijen serta penangkapan buat mematahkan inisiatif para teroris. Kedua, pendekatan lunak (Soft Approach), ialah usaha buat mengurangkan pandangan hidup teroris lewat artikel anti pandangan hidup, kepada pandangan hidup radikal yang mendesak kekerasan politik.

Di bagian yang lain, atas banyaknya peristiwa kelakuan teror serta terorisme di Indonesia, Penguasa menghasilkan Instruksi Kepala negara No 4 Tahun 2002 dalam bagan mengatasi aksi terorisme. Bersumber pada Ketetapan Menteri Ketua Aspek Politik serta Keamanan No: Kep-26 atau Menko atau Polkam atau 11 atau 2002 dibentuklah Desk Koordinasi Pemberantasan Terorisme (DKPT) dengan kewajiban menolong Menteri Ketua Aspek Politik serta Keamanan dalam merumuskan kebijaksanaan untuk pemberantasan

${ }^{1}$ Petrus Reinhard Golose, Deradikalisasi Terorisme, Humanis, Soul Approach dan Menyentuh Akar Rumput, YPTIK, Jakarta, 2009, hlm 12.

${ }^{2}$ Wahid, et.all., Kejahatan Terorisme Perspektif Agama. Hukum, Refika Utama, Bandung, 2004, hlm 9.

${ }^{3}$ Ibid, hlm 28. 
perbuatan kejahatan terorisme, mencakup penangkalan, penangkalan, penyelesaian, penghentian penanganan, serta seluruh aksi hukum yang dibutuhkan. Setelah itu, bersumber pada Peraturan Kepala negara No 46 Tahun 2010 dibangun Tubuh Nasional Penyelesaian Terorisme (BNPT). Pendirian BNPT ini men catat dimulainya sesi terkini dalam tata cara penyelesaian terorisme yang memajukan tata cara soft approach.

Bisa dibilang usaha pemberantasan terorisme tidak dapat dijalani oleh BNPT tanpa kesertaan serta mengaitkan banyak pihak. Bermacam pihak itu salah satunya merupakan The Nusa Institute yang ialah pihak yang berekanan dengan BNPT yang berawal dari bagian Badan Swadaya Warga (LSM) serta bersangkutan dalam pemberantasan terorisme cocok keahlian serta kepentingannya tiap-tiap. Idealnya bertugas dengan cara terkoordinasi buat membuat sesuatu sinergi. ${ }^{4}$

Dalam kondisi penangkalan terorisme, warga memiliki berperan besar di dalam area sosial serta jadi entitas yang amat vital. Warga disini berfungsi memutuskan ideologisasi, mengetahui kehadiran golongan teroris, ataupun dalam mengendalikan perbuatan cula jaringan kekerasan ini. Kesertaan warga serta area pula penting dalam menguak jaringan terorisme. Semacam misalnya, penahanan jaringan Thorik di Tambora, Jakarta Barat. Penahanan itu tidak bebas dari kedudukan warga buat ikut serta memecahkan jaringan terorisme. Tidak hanya itu, penahanan Ridwan nama lain Ismail Tiongkok yang berawal dari informasi warga. ${ }^{5}$

Berdasarkan beberapa hasil penelitian terdahulu yang menunjukkan bahwa pentingnya antisipasi pencegahan terorisme dari berbagai elemen masyarakat, maka Penulisan ini dimaksudkan untuk berfokus pada upaya pencegahan terorisme dengan menanggulangi paham radikalisme di Masyarakat oleh Kepolisian.

\section{METODE PENELITIAN}

Spesifikasi penelitian adalah deskriptif analitis, dengan metode pendekatan yuridis normative didukung oleh yuridis empiris. Jenis data yang digunakan adalah data sekunder dan data primer. Data sekunder diperoleh dari studi dokumen, data primer diperoleh dengan cara wawancara. Data yang diperoleh kemudian dianalisa secara kualitatif.

\section{PEMBAHASAN}

\section{A. Upaya Pencegahan Tindak Pidana Terorisme Berbasis Peran Serta Masyarakat Oleh Satuan Brimob Kepolisian Daerah Sumbar}

Insiden teror yang sepanjang ini terjalin di Indonesia ialah tanda kalau Indonesia sudah ialah salah satu sasaran pembedahan badan terorisme bagus global ataupun dalam negeri. Tingkatkan kecermatan dengan cara raga sekedar bukanlah lumayan buat mengalami badan terorisme global sebab dengan cara organisatoris golongan itu telah mempunyai pemograman serta perencanaan yang amat diperhitungkan bagus bidang operasional, personil, ataupun sokongan prasarana serta pendanaan.

Untuk Indonesia, penangkalan serta pemberantasan terorisme membutuhkan ketelitian observasi atas kebudayaan, situasi warga, serta kemantapan politik rezim. Ketiga aspek itu amat pengaruhi daya guna hukum itu. Rancangan barat serta negeri Islam

\footnotetext{
${ }^{4}$ Abdurrahman Pribadi, Membongkar Jaringan Terorisme, Abdika Press, Jakarta, 2009, hlm 69.

${ }^{5}$ Hery Firmansyah, Upaya Penanggulangan Tindak Pidana Terorime, Jurnal Mimbar Hukum, Vol. 23,
} No. 2, Juni 2011. 
mengenai arti terorisme amat susah diperoleh oleh Indonesia sebab situasi politik yang terjalin di negara- negara yang berplatform Islam berlainan dengan cara pokok bagus bagian kerangka balik serta kemajuannya dengan yang terjalin di Indonesia. Sedemikian itu pula kebudayaan warga bagus dari negara- negeri itu maupun dari negeri barat berlainan dengan kebudayaan warga Indonesia. Warga Indonesia membenarkan keberadaan multi agama serta multi etnik serta hidup berdampingan dengan cara rukun.

Strategi penyelesaian terorisme yang dicoba oleh Penguasa diimplementasikan lewat usaha melindungi, preemtif, serta represif. Dalam usaha Melindungi, sebab mengenang keterbatasan dari usaha penal hingga butuh terdapatnya penyelesaian kesalahan yang tidak cuma bertabiat penal, hendak namun pula bisa memakai saranasarana ataupun kebijaksanaan yang karakternya non- penal. Usaha non- penal ini ialah sesuatu penangkalan kesalahan, dimana dicoba saat sebelum kesalahan itu terjalin, alhasil usaha ini lebih diketahui dengan usaha yang karakternya melindungi ataupun penangkalan. Ini sepatutnya wajib lebih diprioritaskan dari usaha yang karakternya represif. Terdapat opini yang berkata kalau menghindari lebih bagus dari menyembuhkan. Diamati dari kemampuan serta efektifitas usaha penangkalan lebih bagus dari usaha yang bertabiat represif. Dalam bumi medis pidana sudah disetujui sesuatu pandangan kalau menghindari kesalahan merupakan lebih bagus dari berupaya ceria penjahat jadi bagus kembali, lebih bagus disini pula berarti lebih gampang, lebih ekonomis serta lebih menggapai tujuannya. Bawah hukum kewajiban Kepolisian dalam pemberantasan terorisme merupakan Skep Kapolri No 30 atau VI atau 2003 ialah perbuatan lanjut dari diterbitkannya Undang Undang Pemberantasan Perbuatan Kejahatan Terorisme yang mempertegas wewenang Polri selaku faktor penting dalam pemberantasan perbuatan kejahatan terorisme, sebaliknya Tentara Nasional Indonesia (TNI) (Angkatan darat (AD), Angkatan udara (AU), Angkatan laut(AL)) serta BIN jadi faktor pendukung dalam pemberantasan perbuatan kejahatan terorisme

Pemakaian alat nonpenal selaku usaha buat mengatasi kesalahan yang dicoba oleh Satbrimob Polda Sumbar dengan mengaitkan warga ialah antara lain dengan penyantunan serta pembelajaran sosial dalam bagan meningkatkan tanggung jawab sosial masyarakat warga, kultivasi kesehatan jiwa lewat pembelajaran resmi, agama serta serupanya, kenaikan usaha-usaha keselamatan anak serta anak muda, dan aktivitas langlang serta upaya pengawasan yang lain serta serupanya.

Tujuan dari usaha-usaha non penal itu oleh Satbrimob Polda Sumbar merupakan membenarkan kondisi- kondisi sosial di area wewenang Satbrimob Polda Sumbar, tetapi dengan cara tidak langsung memiliki akibat melindungi kepada kesalahan. Dengan cara biasa penangkalan kesalahan bisa dicoba dengan mencampurkan sebagian tata cara. Tata cara awal merupakan metode moralistic (miring) yang dilaksanakan dengan penyebarluasan ajaran-ajaran agama serta akhlak, perundang- undangan yang bagus serta sarana-sarana lain yang bisa mengekang hasrat buat melakukan kesalahan. Sebaliknya metode kedua merupakan metode abiliosinistik yang berupaya buat membasmi sebab musababnya. Misalnya kita tahu kalau aspek titik berat ekonomi (kemelaratan) ialah salah satu aspek pemicu, hingga upaya buat menggapai keselamatan buat kurangi kesalahan yang diakibatkan oleh aspek ekonomi ialah metode abiliosinistik. Ada pula penangkalan kesalahan lewat pendekatan kemasyarakatan, yang lazim diucap Community Based Crime 
Prevention, mengaitkan seluruh kegiatannya buat membenarkan kapasitas warga dalam kurangi kesalahan dengan jalur tingkatkan pengawasan sosial informal.

Beraneka ragam metode dicoba oleh warga dalam aktivitas penangkalan terorisme di Indonesia. Salah satu perihal menarik yang dicoba merupakan mengadopsi adat lokal buat mengantarkan catatan. Perihal ini dicoba oleh warga ditingkat RT pada beberepa kelurahan di kota Padang. Metode yang dicoba merupakan dengan membuat kegiatan keelokan orang randai. Semacam yang dicoba di Kelurahan Limau Manis. Dalam randai di informasikan bermacam catatan catatan sosial. Catatan social itu berisikan data serta himbauan supaya tidak menjajaki mengerti radikal serta berhati batin kepada seluruh wujud aktivitas yang membidik pada aksi terorisme. Adat- istiadat lokal randai yang teruji sanggup menguatkan daya tahan sosial di tengah warga, komunitas, serta keluarga. Tiap warga bisa ikut serta dalam adat- istiadat ini.

Wujud kesertaan yang lain merupakan badan Satbrimob merangkul figur masayarakat serta figur adat supaya memohon tiap orang berumur yang terdapat turut ikut serta dalam membagikan peringatan, pembelajaran, ataupun wawasan kepada kanakkanak di kelurahan. Baginya, usaha ini bisa efisien buat mengalami perkara terorisme alasannya penemuan dini bisa dicoba keluarga. Jadi, jika terdapat anak terindikasi menjajaki mengerti radikal teroris, telah jadi tanggung jawab orang berumur buat membahas perkara itu. Perihal ini dilaksanakan buat menjauhi tuduh- menuduh di tengah warga.

Disamping usaha represif, pula ada usaha preemtif yang bisa dicoba lewat caracara selaku selanjutnya:

1) Pencerahan anutan agama oleh tokoh- tokoh kharismatik serta kredibilitas besar di aspek keimanan buat mengeliminir ekstrimisme serta radikalisasi uraian anutan agama oleh golongan golongan fundamentalis garis keras.

2) Adaptasi kebijaksanaan politik serta rezim selaku selanjutnya:

a) Merespon desakan politik teroris dengan kebijaksanaan politik yang bisa mengakomodir harapan golongan radikal.

b) Pelibatan kelompok-kelompok radikal yang potensial membidik pada aksi teror dalam penanganan bentrokan dengan cara rukun lewat perbincangan, perundingan, serta serupanya.

c) Ijab izin politik untuk kelompok-kelompok yang beranjak di dasar tanah jadi aksi resmi dengan cara konstitusional.

3) Pelibatan partai politik serta badan kemasyarakatan ataupun badan swadaya warga yang memiliki kecocokan ataupun kesamaan visi serta pandangan hidup dalam perbincangan dengan kelompok-kelompok radikal.

4) Penentuan dengan cara jelas badan teroris serta badan terpaut selaku badan ilegal serta membubarkannya.

5) Program aspek sosial ekonomi, antara lain:

a) Pengentasan kekurangan.

b) Pemerataan pembangunan serta hasil- hasilnya.

c) Invensi alun- alun kegiatan.

d) Pengembangan ketenagakerjaan.

6) Pemberlakuan ganjaran mati kepada pelakon terorisme di Indonesia. 
7) Pengaturan kurikulum pembelajaran paling utama di aspek keimanan buat menghindari disusupkannya ideologi-ideologi ekstrim-radikal dalam cara pembelajaran.

Usaha penyelesaian kesalahan pada hakekatnya ialah sesuatu upaya buat penjagaan warga (social defence) supaya warga bisa bebas dari kesalahan ataupun setidak- tidaknya mengatur kesalahan yang terjalin supaya terletak dalam batas- batas keterbukaan warga.

Terhadap masalah manusiawi serta permasalahan kemasyarakatan ini sudah banyak usaha-usaha yang dicoba buat menanggulanginya. Salah satu upaya penyelesaian kesalahan yang dicoba merupakan dengan memakai alat penal ialah memakai hukum kejahatan dengan sanksinya yang berbentuk kejahatan. Penyelesaian kesalahan dengan memakai hukum kejahatan ialah metode yang sangat berumur, setua peradaban orang itu sendiri. Hendak namun ini tidak bararti kalau pemakaian kejahatan selaku salah satu metode buat mengatasi kesalahan.

Tahap represif yang dicoba oleh penguasa dalam bagan melaksanakan penyelesaian kepada perbuatan kejahatan terorisme merupakan selaku selanjutnya:

1) Pembuatan Tubuh Penyelesaian Perbuatan Kejahatan Terorisme, dan pembuatan dasar spesial selaku tahap pemberantasan perbuatan kejahatan terorisme.

2) Invasi kepada tempat perlindungan pelakon terorisme.

3) Penjatuhan ganjaran kejahatan yang jelas kepada pelakon perbuatan kejahatan terorisme yang sudah teruji bersalah bersumber pada bukti-bukti yang terdapat.

Mengetahui berartinya kedudukan personil dalam mengimbangi perkembangan teknologi serta modus operandi bermacam tipe kesalahan tercantum terorisme, Polri berusaha buat tingkatkan mutu pangkal energi orang, dengan metode membenarkan mutu pembelajaran di area Polri, tercantum pembelajaran reserse serta intelijen di mana guna pelacakan serta analisa diajarkan. Polri pula melangsungkan kerjasama pembelajaran serta bimbingan dengan luar negara, AS, Inggris, Australia, Jepang, Jerman, serta lain-lain dan tingkatkan keahlian kemampuan bahasa asing dalam bagan memudahkan berbicara dengan pihak asing untuk alterasi data buat tingkatkan keahlian penemuan dini.

\section{B. Kendala Dalam Pencegahan Tindak Pidana Terorisme Berbasis Peran Serta Masyarakat Oleh Satuan Brimob Kepolisian Daerah Sumbar}

Kedudukan Penguasa serta warga buat menghindari serta mengatasi terorisme telah membuktikan kesuksesan yang lumayan berarti, namun sedang banyak yang butuh dialami buat menghasilkan perasaan nyaman di warga dari aksi-aksi terorisme. Ada sebagian aspek penghalang para penegak hukum yang beranjak dibidang penyelesaian terorisme dalam melaksanakan usaha penangkalan kepada perbuatan kejahatan terorisme antara lain, Satu, Belum Disahkannya Draft Perbaikan Hukum Terorisme terkini. Sedang terdapatnya bahaya terorisme di Indonesia pula diakibatkan oleh belum terdapatnya parasut hukum yang kokoh untuk aktivitas intelijen buat mensupport usaha penangkalan serta penyelesaian terorisme. Sulitnya menata parasut hukum itu sebab terdapatnya uraian kecil sedangkan golongan pemeluk berkeyakinan, kalau perang melawan terorisme dikira melawan Islam.

Minimnya Sinergitas Antara Pihak Satbrimob dengan Ditintelkam, dalam 
Kaitannya Pembinaan ke warga serta dalam memberdayakan warga dalam usaha pemberantasan teorisme. Sulitnya Melacak Jaringan Teroris serta mempunyai akses yang besar membuat kasus terorisme susah buat dituntaskan. Badan teroris bisa menggunakan bermacam perkembangan teknologi garis besar, semacam internet serta telepon seluler buat memudahkan berbicara dengan kelompoknya. Di sisi itu, para teroris pula memiliki keringanan buat melaksanakan ekspedisi serta pemindahan rute batasan negeri alhasil amat susah buat menyudahi kaitan jaringan terorisme garis besar itu. Alhasil kala terdapat warga yang ikut serta dalam penyelesaian teroirsme bisa dikenal oleh jaringan itu.

Hambatan berikutnya merupakan opini kalau penguasa amat menekankan kalau hal penangkalan terorisme merupakan hal pusat. Perihal ini nampak dari aktivitas aktivitas yang dicoba oleh Satbrimob dimana warga cuma menjajaki saja program serta aktivitas yang diselenggarakan. Situasi ini memunculkan uraian di tingkatan warga kalau mereka cuma jadi pemirsa serta aksesoris aktivitas yang dibawa oleh penguasa pusat.

Kala campur tangan penangkalan tidak berawal dari keinginan serta kepekaan perkara di tingkatan lokal, hendak timbul eksklusivitas program serta aktivitas yang berawal dari pusat. Sepanjang ini, warga serta tokoh-tokoh warga cuma jadi ajakan atau donatur modul dalam tiap aktivitas penangkalan terorisme. Mereka tidak dilibatkan dalam cara formulasi konten ataupun akar yang hendak diulas dalam kegiatan- kegiatan itu walaupun mereka mengenali perkara terorisme di alun-alun. Apalagi, tidak tidak sering mereka memahami sebagian DPO (Catatan Pencarian Orang) yang diluncurkan oleh pihak kepolisian. Di bagian lain, aktivitas penangkalan yang sering dicoba oleh Satbrimob Polda Sumbar memakai bahasa yang dikira sangat besar serta kurang mengindahkan adat lokal. Satbrimob pula sedikit perbincangan langsung di tengah warga buat mengantarkan deskripsi penangkalan terorisme. Perihal ini berimplikasi pada acapnya catatan yang di informasikan tidak mengena di tingkatan warga.

Kendala yang lain merupakan tidak terdapat keberlanjutan aktivitas penangkalan di tingkatan lokal yang dinobatkan oleh warga lokal. Sementara itu, dalam kondisi kesertaan warga, beraneka ragam aktivitas sudah banyak dicoba semacam pembangunan kepribadian, penguatan nilai-nilai Pancasila, kebangsaan, serta Garis Besar Arah Negeri. Tidak cuma warga lokal yang merasakan karakter sentralistis kebijaksanaan penangkalan terorisme di Indonesia.

Perbuatan Kejahatan Terorime ialah salah satu perbuatan kejahatan yang amat susah buat diuangkap, oleh sebab itu tidak hanya menginginkan SDM (petugas kepolisian) yang memiliki keahlian yang ahli pula menginginkan bayaran pembedahan yang tidak sedikit. Oleh sebab itu memerlukan atensi lebih dari penguasa terpaut buat mencari pemecahan dari kasus ini. Salah satu Korps Kepolisian yang mempunyai andil dalam penyelesaian perbuatan kejahatan terorisme merupakan Korps Bagian Mobile (Brimob). Bagi Artikel 2 Pesan Ketetapan Kepala Polri (Skep Kapolri) Nomor. Angket. KEP atau 53 atau X atau 2002 hal Brimob, diklaim kalau Korps Brimob ditugaskan buat melindungi keamanan, paling utama yang berkaitan dengan penindakan bahaya dengan keseriusan besar, dalam usahanya buat mensupport keamanan dalam negara. Brimob jadi daya polisi yang penting dalam operasi-operasi melawan aksi separatisme bersenjata, kekerasan etnik serta agama, serta suasana bentrokan yang lain.

Dalam menghindari serta mengatasi terorisme, Penguasa senantiasa berdasar 
pada prinsip yang sudah didapat tadinya, ialah melaksanakan dengan cara melindungi serta represif yang dibantu oleh usaha penguatan kerangka hukum selaku bawah aksi proaktif dalam menanggulangi kegiatan, paling utama dalam menguak jaringan terorisme. Kenaikan kegiatan serupa intelijen, bagus dalam negara ataupun dengan intelijen asing, lewat tukar- menukar data serta bantuan- bantuan yang lain, lalu ditingkatkan. Buat mempersempit ruang aksi pelakon aktivitas terorisme, Penguasa hendak lalu mendesak lembaga berhak buat tingkatkan razia serta pengawasan kepada kemudian rute orang serta benda di lapangan terbang, dermaga laut, serta area pinggiran, tercantum kemudian rute gerakan anggaran, bagus dalam negeri ataupun antarnegara. Razia serta pengawasan pula hendak dicoba kepada aturan niaga serta pemakaian materi peledak, materi kimia, senjata api serta amunisi di area Tentara Nasional Indonesia (TNI), Polisi, serta lembaga penguasa. Tidak hanya itu, Tentara Nasional Indonesia (TNI), Polisi, serta lembaga penguasa pula lalu melaksanakan analisis mendalam bertugas serupa dengan akademisi, figur warga, serta figur agama. Di sisi itu, diselenggarakannya titel adat serta ceramahceramah hal pengetahuan kebangsaan serta penyebaran buku- buku terorisme bisa mengganti anggapan minus warga kepada tahap Penguasa buat melawan terorisme di Indonesia.

Kenaikan keahlian bermacam dasar anti teror serta intelijen dalam memakai sumber-sumber pokok serta jaringan data dibutuhkan supaya bisa membuat petugas anti teror yang handal serta terstruktur dari Tentara Nasional Indonesia (TNI), Polri, serta BIN. Berikutnya, kegiatan serupa global amat butuh buat ditingkatkan sebab terorisme ialah kasus rute batasan yang mempunyai jaringan serta rute tidak cuma di Indonesia.

\section{KESIMPULAN}

Pelibatan masyarakat pada upaya pencegahan terorisme dapat dilakukan pelibatan tidak hanya dalam pelaksanaan program penanggulangan tindak pidana terorisme tapi juga dalam perencanaan pelaksanaan program sehingga kegiatan yang dilakukan sesuai dengan budaya lokal masyarakat. Agar Satbrimob Polda Sumbar dapat meningkatkan kerjasama dengan Ditintelkam sehingga dalam pemberdayaan partisipasi guna pencegahan terorisme dapat lebih efektif dan tepat sasaran.

\section{DAFTAR PUSTAKA}

Petrus Reinhard Golose, Deradikalisasi Terorisme, Humanis, Soul Approach dan Menyentuh Akar Rumput, YPTIK, Jakarta, 2009.

Wahid, et.all., Kejahatan Terorisme Perspektif Agama. Hukum, Refika Utama, Bandung, 2004.

Abdurrahman Pribadi, Membongkar Jaringan Terorisme, Abdika Press, Jakarta, 2009.

Hery Firmansyah, Upaya Penanggulangan Tindak Pidana Terorime, Jurnal Mimbar Hukum, Vol. 23, No. 2, Juni 2011. 